\title{
Affective assemblages matter in socially just pedagogies
}

\author{
Abdullah Bayat ${ }^{1}$ and Veronica Mitchell ${ }^{2}$ \\ ${ }^{1}$ University of the Western Cape \\ ${ }^{2}$ University of the Western Cape/University of Cape Town \\ Corresponding Author: abbayat@uwc.ac.za
}

(Submitted: 28 September 2019; Accepted: 8 April 2020)

\begin{abstract}
Social justice in higher education is a core concern in South Africa. It involves matters of pedagogy, curriculum, recognition, as well as access to tertiary institutions. In light of the massification of higher education, the question that vexes many educators is how to promote student learning through pedagogical practices that are socially just in themselves and that can also promote social justice. A focus on, and sensitivity to, affect provides a way of addressing this concern. We open up our experiences as educators in different professional fields by using an ethico-onto-epistemological methodology, describing relationships that emerged from our classroom engagements. Affective forces and intensities materialising in our teaching and learning assemblages provide a novel relational approach to enacting social justice. We suggest that an attunement to the affective forces circulating in pedagogical practices has the potential to transform conventional teaching habits thereby promoting socially just teaching.
\end{abstract}

Keywords: affect, assemblages, Business education, Medical education, socially just pedagogies

\section{Introduction}

Growing attention is being focused on social justice in higher education (HE) particularly in South Africa amidst ongoing student protests that have foregrounded the precarity of students, educators, and institutional structures. HE is touted as a potential space for enabling social justice as well as a space for engagement with social justice issues (Davids, 2016; McArthur, 2010). Yet, the many challenges that HE faces, such as the low student throughput and one dimensional and directional teaching, appear to diminish such opportunities. In order to achieve and pursue the mandate of enabling social justice, with regards to pedagogy in particular, various theorists have argued that there should be a shift in pedagogical practices (Freire, 2000; Giroux, 1988). The current emphasis on knowledge transmission which has an overly cognitive bias, ought to move towards increasing the dialogic interactions between students and educators in order to foster critical engagement with 
the social location of knowledge, pay attention to social inequalities, identity matters and more recently, to engage with affect (Zembylas and Bozalek, 2017). These pedagogical moves shift from a narrow focus on normative knowledge acquisition towards a focus on students' learning as a relational event that emerges between students and educators, as well as other bodies. There is a becoming-with multiple forces that include affect, which is about reciprocal relations of power and action. These relationships form the thrust of this paper.

Currently, traditional pedagogies operate through normalised discursive and material conditions in which power is exercised over others via hierarchical systems. Power differentials are reinforced by certain categories such as gender, class and race with the impact of perpetuating and reinforcing differences though different forms of othering (Braidotti, 2013). These troublesome practices reproduce existing inequalities, and further contribute to students being passive recipients rather than encouraging them to find their different voices and to connect with their own lived experiences (Freire, 2000).

In many universities in South Africa and globally, the transmission mode of pedagogical practice is still the normative practice in classrooms. Educators' pedagogical efforts are intended to fill knowledge gaps through a syllabus that is 'presented' to the 'empty' student. Freire (2000) advocated a pedagogy that was aimed at growing students' agency. He saw teaching as dialogical and as a way to enhance students' ability to be active participants in the teaching event. bell hooks (1994) invites us to teach to transgress, challenging us to make our teaching exciting and to make our students partners in the learning event. It is our contention that pedagogies for social justice bring opportunities to engage with an awareness and sensitivity to the affective flows that can facilitate students' learning.

In this paper, we present a pedagogy that works generativity with the ways bodies and materials move one another within the teaching and learning event. It disrupts the status quo of conventional pedagogic relations which tend to exclude or limit productive affective flows. Our concern is that all aspects of conventional teaching, including planning, implementation of teaching and assessment practices can either facilitate or hamper productive affective relations and therefore need to be revised.

\section{Exploring socially just pedagogies (SJP)}

We posit that pedagogy is an epistemological, ontological, affective, political, ethical and activity. By adding the term 'social justice' to pedagogy we refer to Nancy Fraser (2009) who claims that social justice needs to allow for ways to enact an equal distribution of resources, recognition, and participative opportunities. This participatory parity includes reconfiguring educator positionalities and subjectivities, student subjectivities, curriculum design, knowledge, teaching and institutional practices, as well as societal practices. Although much has been written on social justice in teacher education (Cochran-Smith, 2010), on pedagogies that attend to social justice like anti-oppressive 
pedagogy (Kumashiro, 2000), and on bringing about social justice education (Adams and Bell, 2016; Strom and Martin, 2017), in this paper, we focus on teaching practices that go beyond content delivery. We examine how the learner gets shaped by educator practices engaging with affect that addresses power and knowledge inequalities.

We propose that a re-consideration of our pedagogical practices is needed as a decolonizing effort to include concerns for the material implications that e/affect each teaching and learning event (Irwin, 2018). Traditional conceptions of learning set up a hierarchy of knowers thereby providing the educator with enormous epistemic power. Thus, even what is considered knowledge, or whose knowledge counts is a matter of social justice. As lecturers, we operate in a regime in which it is taken for granted that 'pedagogy' involves benign dominance. Even the term, lecturer, reinforces the 'banking method' of pedagogy (Freire, 2000), a deficit model of teaching and learning that makes inappropriate assumptions about students. In contrast, SJP takes an affirmative stance that offers transformative opportunities to all students as desiring bodies wanting to be affected and affecting others (Postma, 2016). Postma (2016: 320) suggests that a 'pedagogy for social justice fosters affect, desire and enjoyment' for educators and students. It facilitates the opening up of new pathways that can also overlap with others - a move away from separation and categorization (Postma, 2016). Issues of ethics are entangled in these practices and particularly relevant for both business and medical education.

In the next section we touch on the multiple debates around socially just pedagogies. Many pedagogical frameworks that focus on social justice attempt to promote social justice in a particular way while simultaneously advancing learning especially with regards to disadvantaged students (Resh and Sabbagh, 2016). Social justice is a key theme in critical pedagogy (Giroux, 1988), authentic pedagogy (Newmann and Associates, 1996), productive pedagogies (Lingard, et al., 2003), transformative pedagogy (Osman and Hornsby, 2017) a pedagogy of discomfort (Zembylas and McGlynn, 2012), among others, and can be included in the wide variety of pedagogies that fall under the term of socially just pedagogies (Bozalek, et al., 2018; Leibowitz, 2016; Moje, 2007). In arguing for a pedagogy for social justice, also considered as a socially just pedagogy, there are many different perspectives (Bozalek, et al., 2018; Moje, 2007). Some SJP's promote curriculum reform (Shay and Peseta, 2016), issues of equity and access for previously disadvantaged students (Chubbuck and Zembylas, 2008), while others take into account curricular content matters that include social justice related issues in courses designed specifically to deal with diversity, racism, and other discriminatory practices (Gordon, et al., 2017).

Another strand of enacting social justice is to practice a pedagogy where opportunities are enabled for students to direct their own learning. Such a response-able pedagogy for social justice aims to render students capable in their responses to injustices (Bozalek and Zembylas, 2017; Bozalek, et al., 2018). On a similar note, Postma (2016) suggests that a pedagogy of social justice 
ought to offer all students ways of becoming that can enhance their capacities, referring to the ethics of becoming-with others including human and other-than-human.

A pedagogy of social justice goes beyond the conception of the transfer and depositing of knowledge. The acquisition of knowledge is seen as an embodied and embedded activity. New insights are experienced through relationships with other bodies that include matter which is generally considered as inert and distant. An educator using socially just pedagogies opens up multidirectional spaces for students to enter into new relations with different knowledges, such as interrogating the social location that produces this knowledge.

We have discussed various conceptualisations of SJP and we now put forward the link to affective relationalities. At the heart of our conceptualisation of SJP is the idea of enabling and developing the capacities of students to respond in the world in a manner that enhances social justice.

\section{Plugging into our ethico-onto-epistemological practices}

Cartesian-based research methodology brings a human-centred perspective with specific procedures used to identify, select, process and analyze information about a topic. Our approach shifts away from this perspective to one in which our relational entanglements arise in a web of discursive, political and material forces (Barad, 2007) disrupting the humanistic centrality aligned to conventional data collection and analysis. Thus, the human subject is decentered, nomadic, multiple, incomplete, complex, and tentacular (Haraway, 2016) and in a constant state of becoming.

An ethico-onto-epistemological practice means that we do not operate from a distance with a dichotomy between epistemology and ontology. Neither is ethics external to our epistemic values. Furthermore, methodology is not an add-on, but an entangled process enacted with our ethicoonto-epistemological approach. Initially, our self-study (a Cartesian-based mode of inquiry) aimed at transformative practices, drawing on multiple qualitative methods that were grounded in the description of practice (LaBoskey, 2004). Our process evolved, shifting towards plugging theory into our practices (Jackson and Mazzei, 2012), becoming a non-representational self-study (Strom, et al., 2018), where the self is disrupted and queered away from seeing itself as objective and outside of narrated experiences of pedagogy. The self is co-constituted through patterns of theory-datawriting.

We draw on Barad's (2007) dynamic process of diffraction ${ }^{1}$ described by the interference of ocean waves that overlap with each other and bend, thereby generating patterns of newness. Diffraction involves a process of cutting together-apart (Barad, 2014). Our thoughts, teaching and writing with theory have been shared, yet also been separate. Barad (2014: 181) reminds us that '[t]here is no ' $\mathrm{l}$ ' that exists outside of the diffraction pattern, observing it, telling its story'. Dolphijn

\footnotetext{
${ }^{1}$ Diffraction was first introduced to feminist research by Haraway (1992). Karen Barad (2007) has expanded on the philosophical implications through Quantum Physics theory and related experiments.
} 
and Van der Tuin (2012: 50) point out that a diffractive methodology is 'a detailed, attentive and careful reading [of] the ideas of one through another'. In summary, our collaborative and diffractive self-study method is not a Cartesian reflection in which we are returning and relooking at our experiences but an emergence of differences in which re-turning occurs. Re-turning refers to a process of turning over and over again that Barad (2014: 168) explains as 'iteratively intra-acting, rediffracting, diffracting anew'. This dynamic process enacts new diffraction patterns that have generated a writing-thinking-teaching-conversing enacted through multiple intra-actions ${ }^{2}$.

Our pedagogical experiences read through a diffractive lens demonstrates how we as educators are 'of the diffraction pattern [and] its ongoing (re)patterning is (re)(con)figuring' us (Barad, 2014: 181, italics in the original). This text has emerged through our writing, theory, experiences, computer screens, keyboards, google docs, etc, all of which were as much contributors to this writing assemblage as we have been. This form of inquiry and writing is non-representational (MacLure, 2013b; Thrift, 2008).

In exploring our different pedagogical practices and classroom activities, we stayed with the trouble (Haraway, 2016) as educators in HE. We attempted to capture moments of wonder, considering them as intra-active and relational (MacLure, 2013a). This process is 'not necessarily a safe, comforting, or uncomplicatedly positive affect' (MacLure 2013a: 229). Our experience resonated with MacLure (2013a: 229) who shares how she feels in these moments of wonder, saying 'I have chosen something that has chosen me, and it is that mutual "affection" that constitutes "us" as, respectively, data and researcher'.

Wonder emerged in our ethico-onto-epistemic-methodology. Data snippets were captured from our teaching practices entangled with theoretical ideas developed in conversation and dialogue. As educators, we examined our teaching assemblages with a focus on social justice, acknowledging that we were not in a neutral or innocent position to 'enact what matters and what is excluded from mattering' (Barad, 2007: 148).

We came together through a research project on socially just pedagogies funded by the South African National Research Foundation where we explored different ways of thinking and working with theory with other educators in HE. We have worked together and apart, rendering each other capable through working with our affective flows and a/effective connections, made possible through writing a/synchronously on Google docs, WhatsApp messaging and calls, as well as faceto-face meetings. The alternative spaces and mediums have enhanced our theoretical and practical entanglements and relationships, resonating with our creative efforts in class engagements. Abdullah $^{3}$ teaches in the School of Business and Finance at the University of the Western Cape (UWC),

\footnotetext{
${ }^{2}$ Intra-action is a neologism coined by Karen Barad (2007) that refers to the relationships that are enacted between humans and other-than-humans, including matter. It points to the dynamic emergence involving mutual relationships rather than the traditional assumption of pre-existing entities interacting.

${ }^{3}$ For Abdullah, who is a believer in God, this theoretical framework is a heuristic device, a tool for thinking about his research and teaching practice, not a statement of his Islamic beliefs.
} 
and Veronica facilitates health and human rights workshops with medical undergraduate students in the Department of Obstetrics and Gynaecology, at the University of Cape Town (UCT). Our selfinquiry and discomfort felt necessary to assess how our very positions as educators are actually enabled through the positionalities of unequal power (hooks, 1994). These positionalities require a decolonial and transformative approach to enact social justice. Thus, we contribute to the international and local literature on self-study of teaching especially where this is related to social justice outcomes (Cochran-Smith, et al., 1999; Griffiths, et al., 2004; Knowles, 2014; Waghid, 2016).

In the light of social justice concerns, we carefully re/looked at our current pedagogical practices considering possible modifications. We drew insights from the recent and growing turn to affect theory (Clough, 2007; Coleman, 2016; Massumi, 2015; Ott, 2017; Read, 2015; Zembylas, 2006). Affect, in terms of a Deleuzian (1987) understanding (derived from Spinoza's dimension of affectus) is a power to act and to be acted upon as it is an intensive force that 'carries a political valence' (Massumi, 2015: vii). We suggest that the debates on social justice can be complemented by a turn to affect by proposing that affect, which is inherent in relationships, ought to be central to concerns around pedagogical practices.

Our claim is that socially just pedagogical practices require an acknowledgement and generative engagement with the affective forces permeating in and through our pedagogical spaces. Objects, such as buildings, computers, desks, and chairs, are agentic ${ }^{4}$ in their relationality with educators, students and the curriculum. We turn our attention to the relationships happening between multiple bodies. This is an ontological shift which has pedagogical as well as ethical implications. We argue for a re-orientation of thinking about ourselves and our students as an ethical move towards promoting social justice. The conventional colonial anthropocentric viewpoint centres the human as an independent, pre-existing, rational, atomic entity that interacts and engages with others. However, thinking with Barad's (2007) notion of agential realism, we consider the distribution of agency among humans and non-humans who emerge from their coming together, not prior to it. Coming together, instantiates an intra-action (Barad, 2007). As Barad (2012: 77) notes in her interview with Kleinman:

the notion of "intra-action" queers the familiar sense of causality (where one causal agent precedes and produces an effect all by itself), and more generally unsettles the metaphysics of individualism (the assumption that there are individually constituted agents or entities, as well as time and places).

\footnotetext{
${ }^{4}$ For Abdullah, there is an awareness of human beings possessing a consciousness which other materials such as chairs and desks do not have. Yet this consciousness is entangled with the materiality of matter.
} 
Thus, our educator subjectivity and students' subjectivities emerge, when we step into a classroom for example, through the event of intra-action not before the practice of teaching/learning. Importantly, student learning materialises in each intra-action as each student is in a process of becoming-with other bodies that include space, time and matter. Barad's (2007) concept of an ethico-onto-epistemology enables us to consider our pedagogical practices as entanglements where ethics, ontology and knowledge are inseparable in our teaching and learning practices. Such entanglements oppose thinking along separated, linear lines and actions or with binaries, such as subjects and objects. For instance, ethics tends to be a separate component of teaching curricula, needing to be clearly visible illustrating its inclusion but it is inherent and entwined in all processes.

These dynamic entanglements provide for alternative pedagogical opportunities of becoming that are constituted along a continuum of unthought possibilities (Grosz, 2005) with many different learning outcomes. Goodley (2007: 329) puts forward that 'the time is ripe for experimenting with socially just pedagogies towards hope, possibilities and becomings'. Our paper provokes such experimentation referring to our own teaching activities in which we attempt to use an ethico-ontoepistemological lens. With this lens we add affect and assemblages which are concepts that have inspired and guided our current teaching practices. Unlike traditional publications, we do not structure and contain our text within representational modes of method, analysis and findings. Over the past three years, ideas have emerged and been bounced off each other and with others. Moments have been captured leaving us wondering (MacLure, 2013a).

Below we explain affect and assemblage thinking and what it means to engage with affective relations to enable socially just pedagogies. We illustrate how it has guided our practices to productively generate our ethico-onto-epistemology.

\section{Affect}

The affective turn, as coined by Clough (2007) acknowledges different versions of what constitutes affect (Anderson, 2014). Affect is defined by Massumi (in Deleuze and Guattari, 1987: xvii) as 'a prepersonal intensity corresponding to the passage from one experiential state of the body to another and implying an augmentation or diminution in that body's capacity to act'. Affect includes emotions and feelings but is not reduced to them. It is a force that circulates between bodies and their situations as 'a relational dynamic' (Slaby, 2016: 2). What is important to note in terms of teaching, is that affects are 'always embedded in acts and practices' (Zembylas, 2016: 541). Affect is inherent in every intra-action as there is a coming together of forces and agencies from different bodies and assemblages. There is a visceral impact which generates a subjective or emotional interpretation (Hickey-Moody \& Malins, 2007).

We take up the Deleuzian interpretation of affect that brings a focus on the dynamic and varying intensities and capacities that power bodies to move or be moved (Colebrook, 2002). This 
perspective differs from affect considered as 'an elemental state' connected to individuals as referred to in disciplines such as psychology and the neurosciences (Ott, 2017).

With regards to pedagogical practice, we contend that working with and enhancing the intensity of affect to create an embodied/felt excitement can attend to the ethical aspect of our teaching intra-actions. Our observations indicate that conventional pedagogical practices tend to mis-recognise the value of affective engagement indicating a lack of awareness of affect resulting in limited or misplaced attunement. In this paper, we indicate how we became attuned to affect in our practices which we hope might motivate others to work productively with it.

\section{Assemblages}

Affect is constitutive and constituted in assemblages (Malcahy, 2012; Ringrose, 2011). In order to better understand affect we, therefore, focus our attention on assemblage thinking which foregrounds relationships rather than pre-existing discrete and separate entities. Assemblages indicate multiple elements working together in relationships such as computer-studentswhiteboard-educator. The dynamic nature and agentivity of an assemblage is described by Despret (2013: 38) as 'an active process of attunement that is never fixed once and for all'. This agentic attunement is related to the multiple intertwining agencies and forces that move and inspire us and others, with a reciprocal response for 'others to be inspired' (Despret, 2013: 41).

Deleuze and Guattari (1987) used the French term, 'agencement' instead of assemblage, which emphasises the agency and forces that are elicited through relationships. This notion of agencement takes the meaning of agency beyond conventional humanistic thinking associated with autonomous decision-making as it includes the agency of matter. It is important to move from thinking about ourselves and students as a singular 'l' but to rather think relationally in terms of assemblages. Lenz Taguchi (2010: 58) puts forward that:

The challenge for pedagogy then is not to do away with the 'l', but to start thinking about how this "I" is constituted in its relationality and interdependence with others; not just other "I's" but all matters, artefacts and physical intensities and forces around it in the environment.

Teaching practices are dynamic assemblages (Strom, 2015; Strom and Martin, 2017). As Strom (2015: 322) points out, an educator 'is considered one element working within a constellation of multiple elements, all of which work together to jointly construct or shape her teaching practice' and is not the controller of all the elements.

In summary, within the broader framework of agential realism, affect is a dynamic force within and emerging through different assemblages. We contend that the university and its classrooms are sites of affective relationalities that offer potentials for alternative pedagogical practices that are often overlooked. In the next section, we make the argument for an awareness and sensitivity to the 
affective relationalities emerging and circulating in our teaching spaces for enacting socially just pedagogies.

\section{Linking affective assemblages to socially just pedagogies}

Earlier we suggested that socially just pedagogies involve relational processes that can support student agency with regards recognition of difference, access to resources and voice that move beyond unpacking curricular content. In recognising that affect is present in all assemblages, we now make the argument that one way to enact social justice would entail attuning to affect within teaching assemblages.

Since separations are unhelpful as we come into being through our relationships, thinking with and through Barad's (2007) ethico-onto-epistemology, we suggest that tuning into affect offers new opportunities to wrestle with conventional teacher-student interactions. While acknowledging that $\mathrm{HE}$ assemblages change depending on the ebb and flow of different forces related to time, matter and space, we suggest that an attentiveness by educators to affect can influence the intensities of the affective flows of the teaching-learning entanglement enabling new becomings within pedagogical assemblages. Taking our cue from Barad (2007), the subjectivity of educators emerges through the on-going intra-actions of each moment. These intra-actions are assemblages that form and are constituted by affect with the potential to be transformative by impacting on the capacity of bodies to act through the affective intensities within the assemblages.

Because affect circulates and flows within the assemblages that are generated in our pedagogical processes, affect is also constitutive of our HE institutions. For instance, even at the start when a student registers for a degree and a particular module, this intra-action sets up affective relations. Even the course outline influences the affective relations between the student and other bodies like the classroom. Furthermore, once students enter a lecture room, different affective flows of intensities can enable or constrain students to focus or tune in with the educator's intended needs. Healy (2019: 238) points out that 'pedagogy emerges out of mutually constitutive assemblages of bodies, materials, media, affects, atmospheres, and space'. In the conventional method of teaching, educators dominate the teaching event with techniques such as raising their voice or giving direct eye contact to certain groups of students. Even the tests and assignments prescribed by educators can reinforce the student's position of submission. Our contention is that in such assemblages, the educator is using affect to affirm his/her knowledge and power. Thus, when thinking about using affect to instantiate SJP, classroom activities need to be re-attuned as well as assessments, consultation times and places, etc. We ought to ask ourselves, how is the affect associated with this practice shaping the students' knowledge and subjectivity? In particular, assessment practices, with their associated affective intensities, need to be carefully crafted in terms of how they influence the teaching and learning assemblage. 
Because affect is pre-personal within each encounter, we cannot completely control the emerging affective arrangements. The forces and flows are ongoing between the various bodies. However, as these forces are intimately related to power relations, an attentiveness and attunement to students' affective intensities in classroom intra-actions can enable productive and affirmative assemblage arrangements that may counter the ill-effects of the unequal power relations in classrooms between educators and students.

We recognize that caution and sensitivity are needed not to reinforce the normative hierarchy through affect. For instance, when students are kept at a distance, or situated in authoritarian relationships of submissiveness, affective forces may work to maintain this positionality, thereby accentuating the educator/student inequalities, such as when students are silenced (Delpit, 1988). A more productive and affirmative affective assemblage emerges from situations where students are actively engaged in participatory exercises, drawing on their own knowledges and experiences, which are valued and contribute to their learning. Such a process requires facilitating students' voices to be foregrounded in our educational engagements rather than contained and possibly only heard through various forms of protest action. In case studies discussed by Strom and Martin (2017: 119) they confirm the value of assemblage thinking by highlighting the 'co-constructed nature of the teaching activity'. Nordstrom (2015) also makes the point that nonhuman actors need to be acknowledged in an assemblage and in step with Barad (2007) confirms that every intra-action does not have a predictable outcome but that the event is configured by the human and nonhuman dynamic intra-actions. When we recognise and are attentive to the relationships of students' bodies with other bodies, both human and nonhuman, these indeterminate relationships enable new potentials to arise that can foster social justice.

In terms of our own educational practices, we recognize how affect permeates our teaching, leaving some moments to 'glow' for us, as they make a mark on our teaching career, staying with us, leaving us to wonder about these events (MacLure, 2013a). Such encounters with our students are those that we realize are effective and affective in generating students' interest, opening up the capacity within them to actively engage together with joyous desire for their learning. For instance, we have both used drawings with students as a classroom activity, an unusual pedagogical intervention in business education and clinical medicine. Beyond viewing drawing as a participatory learning activity (PLA) (Bozalek, et al., 2010), the drawings have opened up new insights and potentialities through enacting practices that enhance and intensify the affect inherent in assemblages in the process of art-in-the-making, rather than the product of the artwork being the focus of attention. The drawings demonstrated agency in reconfiguring our dynamic teaching assemblages. However, the paradox of working with drawings where there is an intended outcome, is that the dynamic nature of intra-action frequently leads to unexpected outcomes.

We have experimented with new activities that are relational to enact a SJP that facilitates affective transformative possibilities. Deleuze and Guattari's (1987) metaphor of the rhizome is 
relevant here where there is a process starting in the middle and spreading out. The rhizome places emphasis on the connections made and in the making, which seems pertinent in our practices, unlike a traditional lecture, which follows an arborescent top down pattern of thinking and acting with the educator as the central focus and the assumption that learning material is packaged and contained. Traditional learning events such as lectures or tutorials are seen as separate, discrete and linear events of "learning". In rhizomatic thinking the educator is no more the initiator of a learning event with a beginning and an ending. Rather, inquiry begins in the middle with multiple possibilities. According to Deleuze and Guattari (1987: 25), 'a rhizome has no beginning or end, it is always in the middle, between things, interbeing, intermezzo ... proceeding from the middle, through the middle, coming and going rather than starting and finishing' (italics in original). Relationships are created and emerge with different bodies in unpredictable ways. The situated agency and distributed agency unfold among the different bodies in states of movement and flux generating varying levels of affect that produce different effects. For example, there is a strong affective desire that takes hold of many students turning their attention to their mobile devices and particularly to their social media apps. Apart from the device itself, the many software options are offering a force to pull the student in with an intensity of affective forces that is frequently stronger than the educator's lecture. Additionally, the ringing of the mobile phone has a profound and intense force on the affective flows of the classroom. Apart from a contestation between the bodies of the mobile phones and the educator, there are also forces within each mobile device enabling alternative forms of communication.

The dynamic relationships between human and nonhuman bodies allow for some affective forces to become more prominent than others. In the current normative classroom layout, the teaching assemblage comprising students, educator, space and materials situates the educator in a position of control, frequently in the front of the lecture hall implying and instantiating a unidirectional flow of knowledge/power from the educator to the students with the educator having greater opportunity to intensify the affective atmosphere (Anderson, 2014). This is an example of the operation of institutional power co-constituting the teaching assemblage but also a/effectively enacting the inequalities of the subjectivities of educator and student.

In terms of affective assemblage thinking, we ask what the desks-computers-studentscellphones-whiteboard-educator can do differently in their relations with each other and the affective flows? Each body is re-configured through the mutual relationships that emerge in/through our teaching. We suggest that there are endless potentialities which are possible that can be explored based on the ethical practice of an educator that is attuned to the social injustices inherent in all assemblages. We propose that assemblage thinking can enhance the affective capacity of the educator who becomes a body-in-relation to other bodies, both human and nonhuman. We are not looking to give a solution of what an educator's body must do but in line with Kennedy, et al.'s (2013: 62) thinking that 'we are much more capable of acting — that is, affecting and being able to 
affect-after approaching the event with the idea of the infinite ways that bodies and assemblages could possibly act'. Thus, we suggest that the educator ought to approach the teaching event as a rhizomatic space (Waghid, 2014). Teaching rhizomatically would mean engaging in a nonlinear approach to teaching in the classroom assemblage in a way that enhances other bodies' abilities to affect rather than in a way that closes the affective capacity of bodies. Thus, the educator may come into a classroom and experiment with various activities that can potentially stimulate the intensity of the affective flows and relationships by plugging into the lifeworlds of the students. ${ }^{5}$

The examples above illustrate that within each teaching and learning event there are a multitude of forces acting on and with each other creating different affective relations and potential outcomes. Some forces are conducive to the educator's intentions for a particular learning (of the syllabus for example) while others (like the ringing of a mobile phone) are intense frustrations that appear to constrain students' engagement in the teaching event. Rather than attending to the intricacies of mobile technologies, our point here is that the bodies and devices co-constitute ethical teaching assemblages through which socially just becomings can be instantiated. We argue that attuning to affective relationality within teaching assemblages in HE should be considered as a key component for reconceptualising socially just pedagogies.

\section{Case studies}

Professional courses like Business education and Medical education are constrained by practices set up to maintain standards essential for professional board accreditations. However, as educators and researchers in these disciplines, we illustrate how an interdisciplinary approach that draws on philosophical principles more commonly used in the Humanities and Social Sciences can be transformative. In working towards a socially just pedagogy within the context of affect we ask: how can educators augment affect within the learning event when considering that all relationships in the learning assemblages matter?

What follows is a brief description of our interdisciplinary teaching practices with moments that 'glowed' for us, leaving us with a sense of wonder (MacLure, 2013a) in Business education and Medical education. We illustrate how researching our reading-talking-doing through different intraactivities with others (both human and non-human) has informed and transformed our teaching and our thinking about a/effective teaching practices.

In both of our professional courses, curricula tend to be pre-determined with clear boundaries and a focus on achieving the designated learning outcomes. Knowledge and skills are essential components for course outcomes and student progress. Students tend to remain in a static position in the seating arrangements accommodated by the different institutional settings. A common thread in our pedagogical interventions was to encourage students to move with and through their learning, using performance-based pedagogies thus disrupting business-as-usual.

\footnotetext{
${ }^{5}$ This example talks to the value of student epistemologies which is a social justice goal.
} 


\section{Business Education}

\section{Thinking-acting-doing-writing-with Abdullah's classroom assemblage:}

In 2017, I taught an honours-level research course where most students attending the evening classes had work commitments during the day. I intended to stimulate participative classroom practices, but this did not happen, despite my attempts to engage and encourage dialogue through questions, probing students for their opinions and comments. Traditionally, there is an expectation by our students that their educator's role is to provide the relevant facts and lead all the discussions. I recognized that to keep the traditional lecture mode and then to expect a different engagement was unlikely. Bodies in amphitheatre chairs are tuned to passivity. In trying to stimulate change, I asked the students to engage in an ice-breaking exercise by drawing their river of life ${ }^{6}$ using crayons and pencils, and then to present the drawings to one another in small groups. The reconfiguration of seating, drawings, presentations, and stories emerging from the students' life histories was a connecting force between the students. This generative process encouraged students to appreciate their similarities and their different contexts. It allowed for new connections. What was striking for me as an educator, was how the PLA task also enhanced the flow of affective intensities thus changing traditional classroom intra-actions. The reworking of the traditional teaching assemblage enabled students to actively, productively and joyfully engage meaningfully with each other in their small groups. Furthermore, the participatory learning exercise moved the standard binary assemblage of educator-talking-to-student to an expansive assemblage that included bodies intraacting with art materials which animated the affective flow of the classroom assemblage. Students were talking and laughing and positively engaging with one another. The crayons, paper, and the tactile act of drawing were various kinds of materialities along with the bodies and emotions that formed alternative assemblages that opened up students' capacities to affect and be affected. The teaching and learning process moved from a linear, arborescent teaching model to one with openended connections with the potential for developing rhizomatic connections as I moved from group to group engaging and listening to their presentations. The entanglement and mutual relationships of bodies and materials intensified the joy in the dynamic assemblage. This force seemed to overcome the familiar difficulties that arise when teaching a large class in an amphitheater styled lecture hall with seating that tends to diminish engagement, as well as promote separation and distance.

Another example from my supply chain management honours-level course, I was able to build on my insights. Rather than using the conventional PowerPoint slides, students were asked to present their course readings assigned to them using any arts-based performance. At our initial session together, I introduced students to the frozen scene/tableau modality (Branscombe, 2015; Tortello,

\footnotetext{
${ }^{6}$ The river of life is an exercise where students draw the trajectory of their lives and learning using the metaphor of a river (Bozalek and Biersteker, 2010)
} 
2004) with encouragement to take it forward and to use it in a manner that worked for them to act out the content of the readings. The creative student performances brought unusual moments of sheer laughter and joy which were greatly appreciated by the students, as indicated in the course evaluation. There were also roleplays where the injustices in the supply chain were highlighted, such as the exploitation of vulnerable women in the apparel industry in South East Asia (Human Rights Watch, 2019). Students' performances enabled them to witness and experience the discomfort of injustices prevalent in our current manufacturing processes. On another note, a student expressed thanks for the rare opportunity to share his creative and artistic talent with his fellow students.

In terms of affect, the above examples are in significant contrast to my traditional teaching assemblages. For instance, where students are scattered, distanced, disengaged, and passive, and I was standing in front of the class there was an imbalance in the flow of knowledge/power thereby diminishing the affective intensity for students. Yet, when students were drawn into guided interaction within smaller groups using arts-based techniques, there was an enhancement of affective flows that I contend can be used to contribute to students' deep learning and engagement with social justice issues. The above examples and other experiences have made me conscious of the materiality of my body and its impact on the circulation of affect. These pedagogical experiences have also made me cognizant of my responsibility to design teaching and learning activities that can provide multi-directional opportunities for students to be affected and affect others with careful consideration given to all the bodies and materialities of the teaching/learning assemblages especially in terms of responding to the call for creatively going beyond the strictures of neoliberalism in higher education (Cannella and Koro-Ljungberg, 2017).

\section{Medical Education}

\section{Thinking-acting-doing-writing-with Veronica's classroom assemblage:}

In my curricular engagement and research with senior undergraduate medical students in the women's health module, I have used classroom and online activities to encourage students to connect with the different stories emerging from their clinical experiences and to also share their thoughts about the human rights issues related to their encounters. The interconnection between health and human rights is a complex one. It is often difficult for students to grasp the significance for themselves as current students and as future healthcare providers. My focus has been on the troubling clinical encounters where injustices occur and are witnessed by the students. These disruptive events tend to open up conversations where the intensity and expression of affect enacts a force contributing to a socially just pedagogy (Mitchell, 2016). Feedback comments, reinforced by my doctoral research study, have indicated how these moments are enabling affective flows, bringing deeper meaning to the importance of acknowledging human rights violations in students' curricular experiences. 
A pedagogical intervention developed and modified over the past ten years with the Year 4 undergraduate medical students involves their sharing of personal narratives in the classroom where creativity and imagination using multiple modes of expression are encouraged. Students usually act out the scenarios in which they found themselves, frequently associated with intense discomfort. Further discussions together in the classroom examine how they responded or did not respond. Examples roleplayed by students include instances of observing health professionals physically, verbally and emotionally abusing women in labour through actions such as slapping, shouting and doing procedures without informed consent. Other events shared include the neglect of labouring mothers, who are left to birth their babies alone, at times even on the floor (Mitchell, 2019).

When presenting and acting out these clinical events to their peers, students have used roleplays, poetry, music, flashcards, drawings and video recordings made of and by themselves. These often-noisy performances create a novel experience for medical students and those present in the department who hear the unusual sounds travelling along the corridors.

What has emerged from these affective intra-actions is the creation of assemblages where students are becoming-with others including art-in-the-making and other different forms of materiality. Rather than these processes seen as purely human-to-human interactions, a relational perspective illuminates how the affective assemblages are producing a new dynamic for class tasks. Like Abdullah's classroom engagements, in these workshops there is a palpable flow of affective energy that appears to uplift the students in a joyful manner, raising their awareness and desire to connect with human rights issues in a meaningful way. There is a feeling of playfulness in addressing difficult and complex issues. On several occasions, male students have chosen the role of the mother-in-labour agonizing with her pain demonstrating their willingness to engage with discomfort.

What is apparent is that the performances and shared stories promote affective flows. Below are three quotes from the students' workshop feedback:

One doesn't really appreciate the effect that this block has had on [us] until [we] actually sit down and think about it (2015: block 1)

It has allowed me to think through and process some of the terrible experiences of my colleagues. It's really eye-opening and will certainly shape the way I practice clinical medicine in the future (2014: block 3)

I feel that other people can benefit from hearing different experiences. Having learned from other people's experiences ‥ I can only hope that others can learn from mine (2015: block 1) 
These quotes indicate how sharing different stories around students' experiences, opened spaces for expressions of affect with an affective force that contributed to building their capacities to act against injustices within a struggling health system. These performative moments in the classroom provided a force to act differently to the troubling encounters that many students faced in their clinical apprenticeship.

In our classroom assemblages where we are working with the discomforts involving multiple iterations of injustice, the circulating affective forces open up the capacity for a sensitivity towards change. The emerging affective intensity is enacted and co-constituted through the entanglement of student performances and discussions related to women's health, particularly the multiple violations of women's dignity that students confront in their clinical encounters in the current South African health system (Jewkes, et al., 1998; Vivian, et al., 2011). Students' narratives become alive in their becoming-with others. These learning moments enable forceful affective flows that bring rich meaning to the students' curricular experiences as human rights violations are acknowledged thereby enabling and promoting their ability to respond to future troubling encounters.

Each of the student's stories tells stories and multiplies with more stories that matter. We think with Donna Haraway (2016: 12) who puts forward that:

It matters what matters we use to think other matters with; it matters what stories we tell to tell other stories with; it matters what knots knot knots, what thoughts think thoughts, what descriptions describe descriptions, what ties tie ties. It matters what stories make worlds, what worlds make stories.

Students' stories provide an open apparatus for eliciting affective flows rather than attempting to close off their past experiences.

\section{Discussion}

The moments of wonder in our case studies described above highlight how the circulation of affective forces and flows can be affirmatively embraced and generated in two different contexts in HE. Affect was nudged and utilised as a productive component to learning. Although we cannot work directly with affect because it is relational and pre-personal, certain practices and approaches can increase the affective intensity in the learning assemblage. In particular, Abdullah remembers the tightness gripping his body when students were unresponsive to his prompts for class discussions and then the openness that engulfed him as students laughed and played when he first experimented successfully with drama-based participatory pedagogies. The memory of that event remains vivid for him.

The inspiring cases discussed above should not only be considered versions of studentcentered drama or participation but rather they should be considered from the emergent ethico- 
onto-epistemological approach as possibilities for new ways of material and discursive configurations. For example, learning for and about social injustice by taking on the role of acting appears to increase students' capacities for engaging with injustice. The most productive affective moments in our classrooms appear to emerge with and through the intra-activities that increase the affective intensity, and that trouble the status quo for both the students and us, as educators. A key insight was that it is not about being in control of affect but about being moved in the event through the affective flows that were circulating in and through the teaching and learning assemblages, which were amplified through performance-based pedagogies. This generative process which Healy (2016) refers to as pedagogic affect, opened up potentially new ways of relating to learning materials. Pedagogic affect acknowledges the interweaving of cognition with affect as demonstrated by our classroom activities. This also confirms Mulcahy's (2012) contention that affect intensifies and leaves marks on the body through the increasing connections and relations within assemblages thus providing different opportunities for student and educator becomings, such as where the medical male student performed the role of a birthing mother enabling him to experience the intensity of becoming a labouring mother in difficulty. The table in the classroom, that is usually considered inert, became an agentic component of the assemblage-with students enacting the activity of labour and painfulness that emerged in the moment to promote awareness of social injustice.

Our pedagogical practices emanated from our shifts in thinking. We approached our practices as always being entangled in the intra-actions of heterogeneous bodies. As Strom (2015: 1) notes 'teaching is a collectively negotiated activity'. We worked with the affective flows rather than limiting them through the conventional lecture mode.

We think with Strom and Martin (2017) about our rhizomatic teaching in which there is a spreading out of agency with prolific interconnectivity that is co-constituted in the teaching assemblages that give rise to the potential for different ways of learning. This distributive pattern of affective flows contrasts with the closing off of a conventional lecture. Our material-discursive pedagogical practices appeared to foster the emergence of further intra-acting relationships between students, space, time and matter as described above. Students were encouraged to connect the course content to their personal experiences. This led to amplified moments and movements of affect. By opening up to each other in a playful manner, by sharing difficult stories in creative ways, we have provided a pedagogical opportunity for a capacity building process in which many students appear to be rendered more capable in their responses to the complexities of practice in business and in medicine.

We have described examples of taking up affective thinking in our classrooms - a different way of becoming-with others. In considering affective relationality as a central concern for our socially just pedagogical practices, even our class planning changed. In aiming to enable social justice through affective attunement in our teaching assemblages, we realised that every intra-action 
provided an opportunity for enhancing the affective intensity in our teaching assemblages, and for promoting justice:

Justice, which entails acknowledgment, recognition, and loving attention, is not a state that can be achieved once and for all. There are no solutions; there is only the ongoing practice of being open and alive to each meeting, each intra-action, so that we might use our ability to respond, our responsibility, to help awaken, to breathe life into ever new possibilities for living justly. (Barad, 2007: x)

In sum, we recommend that pedagogical affect within curricular assemblages is a key arena for engaging with social justice. There is a largely untapped potential in working with the affective arrangements enacted in teaching and learning. What has become apparent to us is that intraactions between bodies-in-assemblages allow for the intensification of joy, a pleasurable product within the affective teaching relations (Slaby, 2016).

\section{Conclusion}

Affect has great potential to enable socially just pedagogies especially when acknowledging students' and educators' embodied and embedded histories and cultures, which are saturated with affect. Our practices have affirmed that assemblages-in-the making are alive with agentic potential via the affective forces and movements emerging in our classroom teaching entanglements. Student feedback indicates that the intensities elicited from our pedagogical activities, like roleplay and performances, contribute to their learning, understanding, and further motivation for engaging in the pedagogical process. Our thinking-doing-becoming intra-actively interrupted conventional linear, rational, structured thinking. Socially just pedagogies require the dismantling of the hegemonic Cartesian, conventional thinking and practice prevalent in South African HE.

We suggest that practices encouraging participation which explicitly amplify affect are productive for classroom intra-actions that aim to promote social justice. This requires a sensitivity to affective movements. It also necessitates a relational awareness of ourselves as educators in/between the flows of affect; a move to become open and sensitive to/with the affective forces. For instance, using students' experiences in business or healthcare organisations as curricular content is one way to elicit passionate affective flows. Similarly, working towards social justice and the decolonisation of HE can be enhanced by addressing the affective flows within institutions, thereby providing a way to re-think and repair the ongoing colonial practices evident in South African higher education.

Teaching in the professions can be enhanced by educators being prepared to participate as choreographers of a dance on the waves of affect. Movements are necessary to facilitate multiple 
branching out with new connections with and through students' affective engagement in the pedagogical processes; a folding in-between the learning events.

\section{Acknowledgement}

This work is based on the research supported wholly / in part by the National Research Foundation of South Africa, Grant Number 120845.

\section{Author Biographies}

Abdullah Bayat (PhD) is a senior lecturer in the School of Business and Finance at the University of the Western Cape. In his research and teaching, he experiments with drama-based pedagogies. He is a Muslim who cherishes his faith.

Veronica Mitchell is based in the department of Women and Gender Studies at the University of the Western Cape. She facilitates student workshops in the Department of Obstetrics and Gynaecology at the University of Cape Town. Her PhD dissertation investigated medical students' responses to abusive practices witnessed in obstetrics.

\section{References}

Adams, M. \& Bell, L. A. (eds.) 2016. Teaching for Diversity and Social Justice. London: Routledge.

Anderson, B. 2014. Encountering Affect: Capacities, Apparatuses, Conditions. Farnham, UK: Ashgate Publishing Ltd.

Barad, K. 2007. Meeting the Universe Halfway: Quantum Physics and the Entanglement of Matter and Meaning. Durham and London: Duke University Press.

Barad, K. 2012. 'Intra-actions': An interview with Karen Barad by Adam Kleinman. Mousse, \#34. June 76-81.

Barad, K. 2014. Diffracting diffraction: Cutting together-apart. Parallax, 20(3): 168-187.

Boler, M. \& Zembylas, M. 2003. Discomforting truths: The emotional terrain of understanding differences. In P. Trifonas (ed.) Pedagogies of Difference: Rethinking Education for Social Justice. New York: Routledge, 110-136

Bozalek, V., Bayat, A., Gachago, D., Motala, S. \& Mitchell, V. 2018. A pedagogy of response-ability. In Bozalek, V., Braidotti, R., Shefer, T. \& Zembylas, M. (eds.) Socially Just Pedagogies in Higher Education: Critical Posthumanist and New Feminist Materialist Perspectives. London: Bloomsbury Academic, 97-112.

Bozalek, V. \& Biersteker, L. 2010. Exploring power and privilege using participatory learning and action techniques. Social Work Education: The International Journal, 29(5): 551-572. 
Bozalek, V., Carolissen, R. Nicolls, L., Leibowitz, B. Swartz, L. \& Rohleder, P. 2010. Engaging with difference in higher education through collaborative inter institutional pedagogical practices. South African Journal of Higher Education, 24: 1023-1037.

Bozalek, V., Braidotti, R., Zembylas, M. \& Shefer, T. (eds.) 2018. Socially Just Pedagogies in Higher Education: Critical Posthumanist and New Feminist Materialist Perspectives. London: Bloomsbury.

Braidotti, R. 2013. The Posthuman. Cambridge: Polity Press.

Brandenburg, R. \& McDonough, S. 2019. Ethics, self-study research methodology and teacher education. In Brandenburg, R. \& McDonough, S. (eds.) Ethics, Self-Study Research Methodology and Teacher Education. Singapore: Springer, 1-14.

Branscombe, M. 2015. Showing, not telling: Tableau as an embodied text. The Reading Teacher, 69(3): 321-329.

Cannella, G. S. \& Koro-Ljungberg, M. 2017. Neoliberalism in higher education: Can we understand? Can we resist and survive? Can we become without neoliberalism? Cultural Studies $\leftrightarrow$ Critical Methodologies, 17(3): 155-162.

Chubbuck, S. M. \& Zembylas, M. 2008. The emotional ambivalence of socially just teaching: A case study of a novice urban schoolteacher. American Educational Research Journal, 45(2): 274318.

Clough, P. 2007. Introduction. In Clough, P. (Ed.) The Affective Turn: Theorising the Social. Durham and London: Duke University Press, 1-33.

Cochran-Smith, M. 2010. Towards a theory of teacher education for social justice. In Hargreaves, A., Lieberman, A., Fullan, M. \& Hopkins, H. (eds.) Second International Handbook of Educational Change. Dordrecht, Netherlands: Springer, 445-467

Cochran-Smith, M., Albert, L., Dimattia, P., Freedman, S., Jackson, R., Mooney, J. \& Zollers, N. 1999. Seeking social justice: A teacher education faculty's self-study. International Journal of Leadership in Education, 2(3): 229-253.

Colebrook, C. 2002. Understanding Deleuze. Crows Nest, NSW: Allen and Unwin.

Coleman, R. 2016. Affect. Gender: Sources, Perspectives, and Methodologies. London: Macmillan, $15-26$.

Davids, N. 2016. On extending the truncated parameters of transformation in higher education in South Africa into a language of democratic engagement and justice. Transformation in Higher Education, 1(1): 7.

Delpit, L. 1988. The silenced dialogue: Power and pedagogy in educating other people's children. Harvard Educational Review, 58(3): 280-299.

Despret, V. 2013. From secret agents to interagency. History and Theory, 52: 29-44.

Dolphijn, R. \& Van der Tuin, I. 2012. New Materialism: Interviews \& Cartographies. Ann Arbor, MI: New Humanities Press. 
Fraser, N. 2009. Scales of Justice: Reimagining Political Space in a Globalizing World (Vol. 31). Columbia: Columbia University Press.

Freire, P. 2000. Pedagogy of the Oppressed (30th anniversary edition), trans. Myra B. Ramos. New York: Continuum.

Giroux, H. A. 1988. Teachers as Intellectuals: Toward a Critical Pedagogy of Learning. Westport: Greenwood Publishing Group.

Goodley, D. 2007. Towards socially just pedagogies: Deleuzoguattarian critical disability studies, International Journal of Inclusive Education, 11(3): 317-334.

Gordon, S. R., Elmore-Sanders, P. \& Gordon, D. R. 2017. Everyday practices of social justice: Examples and suggestions for administrators and practitioners in higher education. Journal of Critical Thought and Praxis, 6(1): 68-83.

Griffiths, M., Bassa, L., Johnston, M. \& Perselli, V. 2004. Knowledge, social justice and self-study. In Loughran, J. J., Hamilton, M. L., LaBoskey, V. K. \& Russell, T. (eds.) International Handbook of Self-Study of Teaching and Teacher Education Practices. Dordrecht: Springer, 651-707.

Grosz, E. 2005. Bergson, Deleuze and the becoming of unbecoming, Parallax, 11(2): 4-13.

Haraway, D. 1992. The promises of monsters: A regenerative politics for inapproporiate/d others. In Grossberg, L., Nelson, C. \& Treichler, P. A. (eds.) Cultural studies. New York: Routledge, 295337.

Haraway, D. 2016. Staying with the Trouble: Making Kin in the Chthulucene. Durham and London: Duke University Press.

Healy, S. M. 2016. Evaluating Spaces of Pedagogic Affect. In Imms, W., Cleveland, B. \& Fisher, K. (eds.) Evaluating Learning Environments. Rotterdam: Sense Publishers, 235-250.

Healy, S. M. 2019. Cracking open pedagogy: learning 'in' intense environments. Unpublished PhD Diss., Melbourne Graduate School of Education, Australia.

Hickey-Moody, A. \& Malins, P. 2007. Deleuzian Encounters: Studies in Contemporary Social Issues. London, England: Palgrave.

hooks, b. 1994. Teaching to Transgress: Education as the Practice of Freedom. New York: Routledge. Human Rights Watch. 2019. 'Paying for a bus ticket and expecting to fly': How apparel brand purchasing practices drive labor abuses. Available at: https://www.hrw.org/sites/default/files/ report_pdf/wrd0419_web2.pdf (accessed 30 April 2020)

Irwin, J. 2018. Authority through freedom: On Freire's radicalisation of the authority-freedom problem in education. Espacio, Tiempo y Educación, 5(1): 57-69.

Jackson, A. Y. \& Mazzei, L. A. 2012. Plugging one text into another: Thinking with theory in qualitative research. Qualitative Inquiry, 19(4): 261-271.

Jewkes, R, Abrahams, N. \& Mvo, Z. 1998. Why do nurses abuse patients? Reflections from South African obstetric services. Social Science \& Medicine, 47(11): 1781-1795. 
Kennedy, R., Zapasnik, J. McCann, H. \& Bruce, M. 2013. All those little machines: Assemblage as transformative theory. Australian Humanities Review, 55: 45-66.

Knowles, C. 2014. Vulnerability: Self-study's contribution to social justice education. Perspectives in Education, 32(2): 89-101.

Kolehmainen, M., \& Mäkinen, K. 2019. Affective labour of creating atmospheres. European Journal of Cultural Studies, DOI: 10.1177/1367549419886021

Kumashiro, K. K. 2000. Toward a theory of anti-oppressive education. Review of Educational research, 70(1): 25-53.

LaBoskey, V. K. 2004. The methodology of self-study and its theoretical underpinnings. In Loughran, J. J., Hamilton, M. L., LaBoskey, V. K. \& Russell, T. (eds.) International Handbook of Self-Study of Teaching and Teacher Education Practices. Netherlands: Springer, 817-869.

Leibowitz, B. 2016. In pursuit of socially just pedagogies in differently positioned South African higher education institutions. South African Journal of Higher Education, 30(3): 219-234.

Lenz Taguchi, H. 2010. Going Beyond the Theory/Practice Divide in Early Childhood Education: Introducing an Intra-Active Pedagogy. London: Routledge.

Lingard, B., Hayes, D. \&. Mills, M. 2003. Teachers and productive pedagogies: Contextualising, conceptualising, utilising. Pedagogy, Culture and Society, 11(3): 397-422.

MacLure, M. 2013a. The wonder of data. Cultural Studies $\leftrightarrow$ Critical Methodologies, 13(4): 228-232.

MacLure, M. 2013b. Researching without representation? Language and materiality in postqualitative methodology. International Journal of Qualitative Studies in Education, 26(6): 658667.

McArthur, J. 2010. Achieving social justice within and through higher education: The challenge for critical pedagogy. Teaching in Higher Education, 15(5): 493-504.

Massumi, B. 2015. Politics of Affect. Cambridge: Polity.

Mitchell, V. 2016. A diffractive exploration of affect: Learning, research and teaching in obstetrics. South African Journal of Higher Education, 30(3): 235-254.

Mitchell, V. 2019. Medical Students' Response-Ability to Unjust Practices in Obstetrics: A Relational Perspective. Unpublished PhD Diss. University of the Western Cape, South Africa. .

Moje, E. B. 2007. Developing socially just subject-matter instruction: A review of the literature on disciplinary literacy teaching. Review of Research in Education, 31: 1-44.

Mulcahy, D. 2012. Affective assemblages: Body matters in the pedagogic practices of contemporary school classrooms. Pedagogy, Culture \& Society, 20(1): 9-27.

Newmann, F. M. \& Associates. 1996. Authentic Achievement: Restructuring Schools for Intellectual Quality. San Francisco, CA: Jossey-Bass Publishers.

Nordstrom, S. 2015. Not so innocent anymore: Making recording devices matter in qualitative interviews. Qualitative Inquiry, 21: 388-401. 
Ott, B. L. 2017. Affect in Critical Studies. Oxford Research Encyclopedia of Communication, DOI: 10.1093/acrefore/9780190228613.013.56.

Osman, R. \& Hornsby, D. J. (eds.) 2017. Transforming Teaching and Learning in Higher Education: Towards a Socially Just Pedagogy in a Global Context. London: Palgrave Macmillan.

Postma, D. 2016. The ethics of becoming in a pedagogy for social justice. A posthumanist perspective. South African Journal of Higher Education, 30(3): 310-328.

Read, J. 2015. The Affective Economy: Producing and Consuming Affects in Deleuze and Guattari. In Meiborg, C. \& Van Tuinen, S. (eds.) Deleuze and the Passions, New York: Punctum.

Resh, N. \& Sabbagh, C. 2016. Justice and education. In Sabbagh, C. \& Schmitt, M. (eds.) Handbook of social justice theory and research. New York: Springer, 349-367.

Ringrose, J. 2011. Beyond discourse? Using Deleuze and Guattari's schizoanalysis to explore affective assemblages, heterosexually striated space, and lines of flight online and at school. Educational Philosophy \& Theory, 43: 598-618.

Shay, S. \& Peseta, T. 2016. A socially just curriculum reform agenda. Teaching in Higher Education, 21(4): 361-366.

Slaby, J. 2016. Relational affect. Working Paper SFB 1171 Affective Societies 02/16. Available at: http://edocs.fu-berlin.de/docs/receive/FUDOCS_series_000000000562

Strom, K. J. 2015. Teaching as assemblage: Negotiating learning and practice in the first year of teaching. Journal of Teacher Education, 66(4): 321-333.

Strom, K. J. \& Martin, A. D. 2017. Social justice pedagogy and beginning teachers. In BecomingTeacher: A Rhizomatic Look at First-Year Teaching. Rotterdam: Sense Publishers, 11-24.

Strom, K., Mills, T., Abrams, L., \& Dacey, C. 2018. Putting posthuman theory to work in collaborative self-study. In D. Garbett \& Ovens, A. (eds.) Pushing Boundaries and Crossing Borders: SelfStudy as a Means for Researching Pedagogy, Herstmonceux, UK: S-STEP, 35-41.

Thrift, N. 2008. Spatialities of feeling. In N. Thrift (Ed.), Non-Representational Theory: Space/Politics/Affect. London, England: Routledge. 171-195.

Tortello, R. 2004. Tableaux vivants in the literature classroom. The Reading Teacher, 58(2): 206-208.

Vivian, L., Naidu, C., Keikelame, J. \& Irlam, J. 2011. Medical students' experiences of professional lapses and patient rights abuses in a South African health sciences faculty. Academic Medicine, 86(10): 1282-1287.

Waghid, Y. 2014. Pedagogy Out of Bounds: Untamed Variations of Democratic Education (Vol. 61). Rotterdam: Sense Publishers.

Waghid, Z. 2016. A pedagogical approach to socially just relations in a Grade 11 Economics class. South African Journal of Education, 36(2): 01-18.

Zembylas, M. 2006. Witnessing in the classroom: The ethics and politics of affect. Educational Theory, 56(3): 305-324. 
Zembylas, M. 2016. Making sense of the complex entanglement between emotion and pedagogy: Contributions of the affective turn. Cultural Studies of Science Education. 11: 539-550.

Zembylas, M. \& Bozalek, V. 2017. Re-imagining socially just pedagogies in higher education: The contribution of contemporary theoretical perspectives. Education as Change, 21(2): 1-5.

Zembylas, M. \& McGlynn, C. 2012, Discomforting pedagogies: Emotional tensions, ethical dilemmas and transformative possibilities. British Educational Research Journal, 38(1): 41-59. 